\title{
Pengaruh Metode Blanching pada Proses Pengeringan Cabai
}

\author{
Nida Khaerunnisya'a,1,*, Elok Rahmawati ${ }^{\text {b,2 }}$ \\ ${ }^{a}$ Bisnis Jasa Makanan UAD, J1. Pramuka No 42 Yogyakarta, 55161, Indonesia \\ ${ }^{\mathrm{b}}$ Bisnis Jasa Makanan UAD, Jl. Pramuka No 42 Yogyakarta, 55161, Indonesia \\ 1ichaa.ninid@gmail.com, ${ }^{2}$ elokrahmawati86@gmail.com \\ *penulis korespondensi
}

\begin{abstract}
The study aimed to know the effect of preliminary treatment in the form of blanching with sodium metabisulfite solution, and by without treatment. Where the blanching process aims to disable the enzyme contained in the chili pepper. The solution is done with different stages that is with direct exposure, and through the blanching process by giving a mixture of Sodium Metabisulfit (Na2S2O5) solutions and then in blanching with some different times that are 3 minutes, 7 minutes, and 11 minutes. The result is that chili peppers that glare through the blanching process have better color, scent, and taste than chili that does not go through the blanching process. The treatment differences exert influence on randements, scents and colors in powdered chili.
\end{abstract}

Keywords: blanching, chili, drying

\section{ABSTRAK}

Penelitian ini bertujuan untuk mengetahui pengaruh perlakuan pendahuluan berupa blanching dengan larutan natrium metabisulfite, dan dengan tanpa perlakuan. Dimana proses blanching bertujuan untuk menonaktifan enzim yang terdapat didalam cabai. Peneletian dilakukan dengan tahapan berbeda yaitu dengan penjemuran langsung,dan melalui proses blanching dengan memberikan campuran larutan Natrium Metabisulfit (Na2S2O5) dan kemudian di blanching dengan beberapa waktu yang berbeda yaitu 3 menit, 7 menit, dan 11 menit. Hasilnya cabai yang melalaui proses blanching memiliki warna, aroma, dan rasa yang lebih baik dari pada cabai yang tidak melalui proses blanching. Perbedaan perlakuan memberikan pengaruh pada randemen, aroma, dan warna pada cabai bubuk.

Kata Kunci: blanching, cabai, pengeringan

\section{Pendahuluan}

Cabai merah (Capsicum annuum L) merupakan tanaman hortikultura yang banyak dimanfaatkan untuk kebutuhan pangan, (Rukmana dan Oesman 2006). Cabai merah merupakan pangan penting pada masyarakat Indonesia. Hampir semua rumah tangga mengkonsumsi cabai setiap hari sebagai pelengkap dalam hidangan keluarga sehari-hari. Konsumsi cabai ratarata di Indonesia sebesar 4,6 kg per kapita per tahun (Direktorat Pengolahan Hasil Pertanian, 2009).

Pada umumnya penanganan cabai pasca panen masih sangat sederhana atau masih sedikit dimanfaatkan sehingga mengakibatkan tingkat kerusakan cabai masih sangat tinggi. Hal ini terjadi karena fasilitas teknologi dan pengetahuan petani tentang penanganan pascapanen belum memadai atau masih terbatas. Cabai merupakan sayuran yang memiliki tingkat kerusakan yang cepat jika dipertahankan dalam bentuk segar, sehingga perlunya penangan pasca panen yang baik seperti dikeringkan. Saat ini cabai dipasaran sudah banyak yang di 
pasarkan dalam bentuk kering selain praktis tentunya juga memiliki umur simpan yang jauh lebih lama dari cabai segar. Oleh karena itu perlu dilakukan upaya untuk memperpanjang umur simpannya melalui upaya pengolahan, seperti cabai kering, bubuk cabai, saus cabai, dll (Direktorat Pengolahan Hasil Pertanian, 2009).

Tujuan dari pengeringan adalah mengurangi kadar air bahan sampai batas dimana mikroorganisme dan kegiatan enzim yang dapat menyebabkan pembusukan akan terhenti, dengan demikian bahan yang dikeringkan dapat mempunyai waktu simpan yang lama. Disamping itu juga pengolahan dapat digunakan untuk meningkatkan nilai tambah (added value) suatu produk (Yuarni, dkk, 2015).

Kualitas bubuk cabai sangat ditentukan oleh proses pembuatannya, seperti cara sortasi, blanching, pengeringan, pengemasan dan penyimpanan (Direktorat Pengolahan Hasil Pertanian, 2009). Untuk memaksimalkan nilai jual pada cabai, dapat dilakukan pemanfaatan teknologi pasca panen yang lebih baik seperti di-blanching.

Proses blanching bertujuan untuk mencegah perkembangan bau dan warna yang tidak dikehendaki selama pengeringan dan penyimpanan. Blanching akan menyebabkan udara dalam jaringan keluar dan pergerakan air tidak terhambat sehingga proses pengeringan menjadi cepat (Anonim, 2012) dengan cara merendam cabai rawit (Capsicum frutescens).

Tujuan utama dari blanching adalah untuk menonaktifkan enzim (Feri et al,2018). Enzim yang dinonaktifkan adalah enzim-enzim yang dapat membantu mempercepat pembusukan dan perubahan warna. Blanching akan menyebabkan udara dalam jaringan keluar dan pergerakan air tidak terhambat sehingga proses pengeringan menjadi lebih cepat.

Menurut Hartuti dan Sinaga (1993) penambahan natrium metabisulfit 0,2 \% yang digunakan sebagai bahan pencelup menghasilkan cabai rawit kering dengan warna yang lebih biak dan kandungan vitamin $\mathrm{C}$ yang lebih tinggi dibandingkan dengan cabai rawit tanpa menggunakan natrium metabisulfit. Batas maksimum penggunaan natrium metabisulfit menurut Depkes (1990) adalah 3000 mg/liter (as cited in Akhyar Ali et al, 2002).

Dalam penelitian ini proses blanching lebih ditujukan untuk menghambat proses pencoklatan dalam pembuatan bubuk cabai. Selain blanching, salah satu cara untuk menghambat reaksi pencoklatan adalah dengan perendaman dalam natrium metabisulfite (Na2S2O5). Natrium metabisulfit dapat berinteraksi dengan gugus karbonil, hasil reaksi tersebut dapat mengikat melanoidin sehingga mencegah timbulnya warna coklat (Chatrine, dkk. 2013). Penelitian ini dilakukan untuk mengetahui pengaruh perlakuan pendahuluan berupa blanching dengan larutan natrium metabisulfit. Dan dengan tanpa perlakuan. Waktu blanching yang digunakan adalah waktu yang berbeda-beda yaitu selama 3 menit, 7 menit, dan 11 menit dengan suhu $90^{\circ} \mathrm{C}$.

\section{Metode Penelitian}

Penelitian ini merupakan penelitian eksperimental dengan rancangan acak menggunakan faktor perlakuan pendahuluan berupa blanching dan penambahan larutan natrium metabisulfit. 


\section{Bahan}

Bahan-bahan yang digunakan dalam penelitian ini antara lain 175 gram Cabai keriting matang penuh, 0,2\% Natrium Metabisulfit (Na2S2O5), dan 1 liter Air, atau lebih agar cabai tercelup rata.

\section{Metode}

1. Persiapan bahan baku, cabai yang digunakan dalam penelitian ini adalah cabai merah keriting. Sebelum dilakukan penelitian cabai dipastikan matang penuh.

2. Sortasi dan pembersihan, cabai yang sudah disiapkan kemudian dipilih yang kualitasnya baik, bebas hama dan penyakit, segar, kemudian tangkai cabai dibuang. Setelah cabai tidak bertangkai cabai di cuci bersih kemudian dibelah untuk dihilangkan isinya.

3. Perlakuan cabai, cabai yang sudah siap selanjutnya dibagi menjadi beberapa tahapan perlakuan ada yang tidak di-blanching atau langsung dijemur, dan di-blanching dengan waktu yang berbeda-beda yaitu selama 3 menit, 7 menit, dan 11 menit dengan suhu $90^{\circ} \mathrm{C}$ menggunakan larutan Natrium Metabisulfit (Na2S2O5) sebanyak 0,2\% dari pelarut. Untuk membuat larutan pencelup dalam 1 liter air, sodium metabisulfit ditimbang 2 gram, dan larutkan sodium meta bisulfit sedikit demi sedikit dengan air yang bersih, setelah larut tambahkan kedalam air.

4. Pengeringan, cabai yang tidak di-blanching maupun yang di-blanching kemudian di taruh di tampah dan dikeringkan dengan menggunakan sinar matahari hingga benarbenar kering merata, sambil diamati setiap perubahannya.

5. Penghalusan, cabai yang telah kering merata selanjutnya dihaluskan hingga menjadi bubuk cabai.

\section{Hasil dan Pembahasan}

Hasil penelitian menunjukkan bahwa pengaruh perbedaan perlakuan blanching dan tanpa blanching dan berdasarkan lamanya waktu blanching memberikan pengaruh terhadap parameter yang diamati.

Tabel 1. Pengaruh Perbedaan Perlakuan Blanching dan Tanpa Blanching terhadap Kualitas

Cabai Kering

\begin{tabular}{lcccc}
\hline \multicolumn{1}{c}{ Parameter mutu } & 3 menit & 7 menit & 11 menit & Tanpa perlakuan \\
\hline Berat awal $(\mathrm{g})$ & 175 & 175 & 175 & 175 \\
\hline Berat tanpa biji $(\mathrm{g})$ & 105 & 105 & 105 & 105 \\
\hline Berat bubuk total $(\mathrm{g})$ & 9.9 & 11.1 & 14.2 & 8.6 \\
\hline $\begin{array}{l}\text { Rendemen } \\
\text { Pengeringan }(\%)\end{array}$ & 9.43 & 10.57 & 13.52 & 8.19 \\
\hline Aroma & $\begin{array}{c}\text { Agak } \\
\text { menyengat }\end{array}$ & Menyengat & $\begin{array}{c}\text { Aroma pedas } \\
\text { yang } \\
\text { menyengat }\end{array}$ & $\begin{array}{c}\text { Tidak terlalu } \\
\text { menyengat }\end{array}$ \\
\hline Warna & $\begin{array}{c}\text { Agak } \\
\text { merah }\end{array}$ & Merah & Merah gelap & Merah pucat \\
\hline
\end{tabular}

Dari data diatas dapat dilihat bahwa lama waktu perendaman memberikan pengaruh pada randemen, aroma dan warna pada cabai bubuk. Cabai tanpa perlakuan mengalami penurunan 
berat yang banyak. erlakuan blanching selama waktu tertentu pada pengeringan cabai merah dapat mempengaruhi karakteristik pengeringan cabai merah.

\subsection{Penyusutan Berat Cabai}

Semakin lama di keringkan cabai akan semakin mengalami penyusutan berat hal ini terjadi karena adanya proses respirasi yang menyebabkan cabai kehilangan kandungan air didalamnya dan akan semakin sedikit penurunan beratnya

Berdasarkan hasil pengamatan, saat sudah kering,berat cabai yang di-blanching dengan waktu 11 menit akan mengalami sedikit saja penurunan berat.

\subsection{Perubahan Warna Cabai}

Berdasarkan hasil pengamatan perubahan warna cabai, warna cabai berubah menjadi semakin gelap pada cabai yang memiliki waktu blanching 11 menit. Cabai yang tidak diblanching lebih lama proses pengeringannya, dan warnanya cenderung merah pucat. Warna cabai yang paling bagus yaitu dengan perendaman selama 7 menit. Tingkat kecerahan pada perlakuan blanching dengan natrium bisulfit selama 3 dan 11 menit memiliki warna yang berbeda nyata.

\subsection{Aroma Cabai}

Berdasarkan hasil pengamatan cabai yang memiliki aroma paling menyengat adalah cabai yang memiliki waktu blanching 11 menit

\section{Kesimpulan}

Cabai yang mengalami proses blanching warnanya merah tua, dan cabai yang tanpa perlakuan blanching berwarna merah cerah cenderung pucat. Rasa cabai bubuk yang mengalami proses blanching lebih pedas daripada cabai tanpa proses blanching. Cabai yang mengalami proses blanching mengalami penurunan berat lebih banyak daripada berat cabai tanpa blanching. Efisiensi pengeringan paling tinggi pada perlakuan blanching selama 7 menit dikarenakan warna pada bubuk cabai yang bagus. Aroma cabai yang paling menyengat pada waktu blanching 11 menit.

\section{Pustaka}

Ali, Akhyar dkk. 2002. Pengaruh Konsentrasi Natrium Metabisulfit dan Lama Blanching Terhadap Mutu Cabai Merah (Capsicum annuum L.) Kering. Vol 1, No. 1 : 19-26. Fakultas Pertanian: Universitas Riau, Pekanbaru.

Chatrine, dkk. 2013. Kajian Sifat Fisik Dan Kimia Tepung Labu Kuning (Cucurbita maxima) dengan Perlakuan Blanching dan Perendaman Natrium Metabisulfit (Na2S2O5). Vol 2, No 2, Hlm 122. Fakultas Pertanian. Universitas Sebelas Maret. Surakarta. 
Direktorat Pengolahan Hasil Pertanian Direktorat Jenderal Pengolahan dan Pemasaran Hasil Pertanian Departemen Pertanian. 2009. Standar Prosedur Operasional (SPO) Pengolahan Cabe. Jakarta: Direktorat Pengolahan Hasil Pertanian.

Feri,dkk. 2018. Pengaruh Blanching Terhadap Kualitas Cabai Merah (Capsicum annuum L). Naskah Publikasi (2018). Fakultas Pertanian: Universitas Muhammadiyah Yogyakarta.

Rukmana, R., Y.Y. Oesman. 2006. Bertanam cabai dalam pot. Kanisius, Yogyakarta.

Yuarni, Desi., Kadirman, Jamaluddin. 2015. Laju Perubahan Kadar Air, Kadar Protein dan Uji. 
